\title{
PKM PENINGKATAN KOMPETENSI GURU FISIKA SMA DALAM MENGEMBANGKAN KEMAMPUAN PEMBUATAN ALAT PRAKTIKUM
}

\author{
Tulandi Djeli \\ Jurusan Fisika FMIPA Universitas Negeri Manado \\ email : djelitulandi02@gmail.com
}

\begin{abstract}
ABSTRAK
Pendidikan merupakan kunci untuk semua kemajuan dan perkembangan yang berkualitas, sebab dengan pendidikan manusia dapat mewujudkan semua potensi dirinya baik sebagai pribadi maupun sebagai warga masyarakat. PKM peningkatan kompetensi guru fisika SMA dalam mengembangkan kemampuan pembuatan alat praktikum merupakan salah satu upaya meningkatkan mutu pendidikan, terutama peningkatan kualitas pembelajaran fisika di SMA. Tujuan kegiatan pengabdian ini adalah Meningkatkan kompetensi guru dalam melaksanakan pembelajaran dengan pendekatan saintifik, meningkatkan kemampuan guru menyusun bahan ajar berbasis lab dan Meningkatkan kemampuan guru merancang peralatan laboratorium. Hasil kegiatan pengabdian ini telah dibuat peralatan lab. sederhana venturimeter tanpa manometer dan venturimeter dengan manometer. Juga dibuat alat demonstrasi hukum kekekalan momentum dan alat demonstrasi tumbukan dan momentum. Hasil pre tes untuk melihat pengetahuan kognitif para guru tentang materi terkait peralatan lab. yang dibuat masih rendah namun setelah diberi pendampingan dan pelatihan kemampuan kognitifnya meningkat. Hasil uji keberfungsian alat menunjukkan bahwa alat yang dibuat ini layak digunakan dalam pembelajaran fisika di SMA.
\end{abstract}

Kata kunci: peralatan laboratorium, kompetensi guru fisika 


\section{PENDAHULUAN}

Fisika merupakan salah satu cabang IPA yang mendasari perkembangan teknologi maju dan dengan fokus kajian pada energi dan alam. Upaya memperbaiki dan meningkatkan mutu pendidikan seakan tidak pernah berhenti. Banyak agenda reformasi pendidikan yang telah dilaksanakan. Beragam program inofatif ikut serta memeriahkan reformasi pendidikan. Reformasi pendidikan adalah restrukturisasi pendidikan, yakni memperbaiki pola hubungan sekolah dengan lingkunganya serta dengan pemerintah, pola pengembangan perencanaan dan pola pengembangan manajerialnya, pemberdayaan guru dan restrukturisasi pembelajaran.

Kurikulum 2013 menghendaki semua mata pelajaran diajarkan dengan pendekatan scientific melalui mengamati, menanya, mencoba, menalar, dan mengomunikasikan, maka untuk mata pelajaran IPA fungsi laboratorium (lab) sekolah mempunyai peranan sangat penting. Sarana ruang, peralatan serta bahan, pengelolaan dan tenaga laboratorium (laboran) adalah komponen yang tidak bisa dipisahkan satu dengan yang lainnya.

Kegiatan pembelajaran Fisika memang tidak harus dilaksanakan di dalam ruang lab, dan bahan praktik bisa digantikan dengan bahan sederhana yang ada di sekitar kita. Namun, mengoptimalkan pengelolaan lab adalah sebuah keniscayaan untuk mendukung pelaksanaan pembelajaran seperti yang diharapkan.

Secara umum standar sarana prasarana laboratorium fisika SMA telah terpenuhi, tetapi untuk standar tenaga laboratorium belum terpenuhi. Laboratorium fisika SMA belum memiliki tenaga teknisi, bahkan kepala laboratorium dan laboran yang ada belum memiliki kompetensi yang cukup dalam pengelolaan laboratorium.
Sehingga diperlukan program peningkatan sumberdaya manusia baik teknisi lab.maupun guru bidang studi.

Melalui kegiatan PKL mahasiswa di beberapa sekolah SMA di Tondano dan sekitarnya diperoleh informasi bahwa guru-guru fisika belum memaksimalkan Lab. Untuk mendukung pembelajaran. Hal ini disebabkan karena banyak peralatan Lab. yang sudah tua dan tidak dapat dipakai lagi, tapi juga kurangnya kemampuan guru dalam mengembangkan peralatan-peralatan lab. sederhana yang dapat digunakan dalam pembejaran berbasis praktikum. Karena itu perlu ada kegiatan untuk membangun semangat dan inovasi guru dalam mengembangkan peralatanperalatan Lab.sederhana tapi memenuhi standar pembelajaran sehingga proses belajar dengan pendekatan saintifik dapat dilaksanakan. Dalam permen 65 tahun 2013 antara lain menyebutkan:(1)Mendorong peserta didik untuk selalu mencari tau (2) Guru bukan satu-satunya sumber belajar tapi harus berbasis aneka sumber belajar(3) Pendekatan tekstual menuju proses sebagai penguatan penggunaan pendekatan ilmiah;

(4) Pembelajaran berbasis konten menuju pembelajaran berbasis kompetensi; (5) Pembelajaran parsial menuju pembelajaran terpadu;

Pembelajaran berbasis lab. akan melengkapi keseluruhan proses pembelajaran di sekolah sehingga dengan demikian proses pembelajaran secara utuh melahirkan kualitas pribadi yang mencerminkan keutuhan penguasaan sikap, pengetahuan, dan keterampilan

\section{METODE}

Metode dalam kegiatan pengabdian ini Dengan melakukan pendampingan dan pelatihan bagi guru-guru fisika baik yang ASN maupun yang belum.

Teknik analisis data dalam kegiatan pengabdian ini dilakukan dengan 
mendeskripsikan data yang diperoleh.Data yang dideskripsikan adalah data tentang pengetahuan kognitif guru dalam penguasaan konsep momentum dan dinamikan fluida khususnya yang melibatkan praktikum dan demonstrasi.

\section{Hasil Penelitian dan pembahasan Pembuatan alat}

Setelah semua komponen tersedia, maka pembuatan alat peraga dapat dilakukan mengikuti desain yang sudah ada. Hasil dari tahap pembuatan alat peraga ini, adalah sebagai berikut :

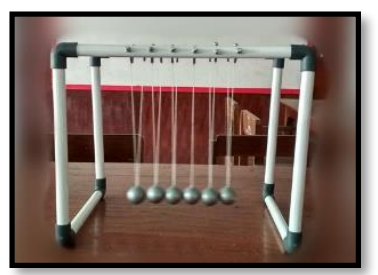

Gambar 3. Alat demonstrasi hukum kekekalan momentum

\section{Merancang desain awal}

Tabel 4. Desain awal

Nama dan tujuan
alat peraga
Alat demonstrasi
Hukum Kekekalan
Momentum
Alat peraga ini
bertujuan untuk
menunjukkan
konsep kekekalan
momentum
Alat praktikum
Momentum dan
Tumbukan
Alat ini bertujuan
untuk
menunjukkan
konsep tumbukan
dan momentum

Tabung Venturimeter Tanpa
Venturimeter adalah alat yang digunakan untuk mengukur kelajuan zat cair.

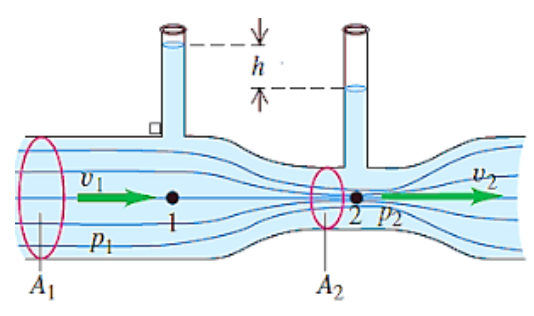

Venturimeter dengan Manometer

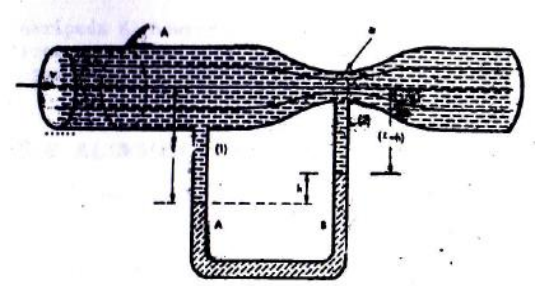

Sumber : Sutrisno.1984 : 252

Alat lab. ini digunakan untuk

mengukur laju aliran fluida

Venturimeter Dengan Manometer

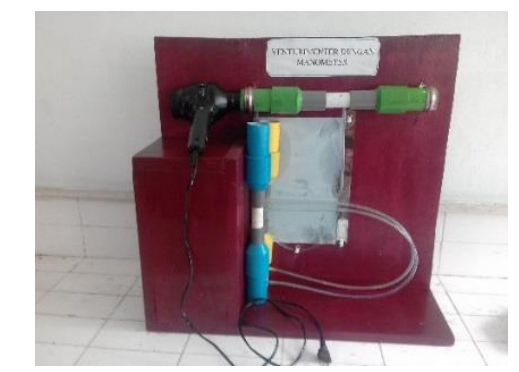

Gambar 4. Venturimeter Dengan Manometer

Uji keberfungsian untuk alat praktikum venturimeter dengan manometer menetapkan tiga variabel meliputi variabel terikat yaitu kecepatan aliran udara $(v)$, variabel bebas meliputi diameter pipa 2 $\left(d_{2}\right)$, massa jenis zat cair dalam selang manometer $\left(\rho^{\prime}\right)$, variabel kontrol meliputi diameter pipa $1\left(d_{1}\right)$, dan zat alir yang mengalir didalam pipa $(\rho)$. Pengolahan data untuk pengukuran kecepatan aliran udara dengan menggunakan air dalam selang manometer disajikan dalam bentuk grafik sebagai berikut

Validasi Akhir Oleh Pakar/Ahli Untuk Alat Praktikum Venturimeter Tanpa 
Manometer

\begin{tabular}{cc}
\hline Pakar/Ahli & \% Kelayakan \\
\hline Ahli Materi 1 & $95 \%$ \\
Ahli Materi 2 & $100 \%$ \\
Ahli Media 1 & $92,59 \%$ \\
Ahli Media 2 & $96,29 \%$ \\
\hline
\end{tabular}

Hasil validasi untuk alat dan penuntun praktikum fluida dinamis berada pada rentang interpretasi skor $81 \%-100 \%$. Hasil tersebut didukung oleh hasil penelitian Alifah, Sifa (2016) bahwa hasil uji set alat praktikum fluida dinamis terhadap ahli dan siswa memperoleh tingkat penilaian yang sangat baik yaitu berada pada rentang interpretasi skor $81 \%-100 \%$.

\section{KESIMPULAN}

Berdasarkan kegiatan PKM Peningkatan kompetensi guru fisika SMA dalam mengembangkan kemampuan pembuatan alat praktikum yang telah dilakukan, maka dapat disimpulkan bahwa;

Rancangan dan pembuatan alat peraga menggunakan matriks menghasilkan rentetan materi dan alat praktikum yang dapat mengintegrasikan konsep Impuls dan Momentum dengan konteks kegiatan praktikum.

Rancangan kegiatan praktikum berdasarkan proses sains dapat menuntun siswa mempelajari materi Impuls dan Momentum melalui berbagai pendekatan pembelajaran.

Peralatan praktikum fluida dinamis layak digunakan untuk praktikum Fisika Dasar karena telah melalui tahap validasi awal ahli materi dan ahli media, uji keberfungsian alat dan penuntun praktikum dan validasi akhir oleh ahli materi dan ahli media.
Arief S Sadiman, dkk. 2008. Media Pendidikan. Jakarta : PT Raja Grafindo Persada.

Aufa, Ahmad. (2016). Pengaruh Rasio Diameter Pipa Terhadap Perubahan Tekanan Pada Bernoulli Theorem Apparatus. Jurnal Prodi Teknik Mesin Universitas PGRI Banyuwangi,1 (1), 711.

Alfiyah Sifa. (2016). Pengembangan Set Praktikum Fluida Dinamis Untuk

Sekolah

Menengah Atas (SMA) Kelas XI.Jurnal Penelitian \& Pengembangan Pendidikan Fisika, 02(2), 47.

Azhar. (2011). Karakteristik Fisika dan Realita Pendidikan Fisika Nasional. Jurnal Tabularasa PPS UNIMED. Vol. 8 , No. 2 http://digilib.unimed.ac.id. Diakses pada tanggal 30 Januari 2018

Alwi, S. (2017). Problematika Guru dalam Pengembangan Media Pembelajaran. EJurnal IAIN Lhokseumawe. Vol. 8, No. 2

http://ejurnal.iainlhokseumawe.ac.id.

Diakses pada tanggal 28 Februari 2018

Kanginan, M. (2006). Fisika untuk SMA Kelas XI. Jakarta : Penerbit Erlangga

Preliana, E. (2015). Pengembangan Alat Peraga Sains Fisika Berbasis Lingkungan Untuk Materi Listrik Statis pada Siswa Kelas IX SMP Negeri 3 Pleret. JRKPF UAD, Vol. 2 No. 1 http://journal.uad.ac.id. Diakses pada tanggal 21 Februari 2018

Septiadi, Nata W.(2008). Studi eksperimental

Orifice Flow Meter Dengan Variasi Tebal Dan Posisi Pengukuran Beda Tekanan Melintas Orrifice Plate. Jurnal Ilmiah Teknik Mesin Cakram, 2(1), 6168.

\section{DAFTAR PUSTAKA}

